\title{
РАЗДЕЛІ. ЭКОНОМИКА
}

\section{Санталова М.С., Борщева А.В., Кубланов А.М. Качество человеческого капитала}

Автономная некоммерческая организация дополнительного профессионального образования «Альфа Русс» Московский экономический институт (Россия, Москва) Воронежский государственный институт физической культурь doi:10.18411/spc-8-03-2018-14

(Россия, Воронеж) idsp: 000001:spc-8-03-2018-14

\section{Аннотация}

В статье рассматривается процесс формирования и расходования человеческого капитала по этапам жизненного цикла индивида. Предмет исследования - человеческий капитал и оценка его качества. Цель исследования - уточнить структуру человеческого капитала, выявить особенности его оценки.

Делается вывод о наличии следующих составляющих человеческого капитала: капитал здоровья, капитал образованности, интеллектуальный капитал, профессиональный капитал, трудовой капитал, капитал менеджера, капитал социальной адаптации. Приводятся доводы о том.что качество сформированного человеческого капитала индивида можно подтвердить различными формами общественной и государственной оценки.

Ключевые слова: качество человеческого капитала, структура человеческого капитала, капитал здоровья, капитал образованности, интеллектуальный капитал, профессиональный капитал, капитал социальной адаптации, трудовой капитал, капитал менеджера

\section{Annotation}

The article considers the process of formation and expenditure of human capital on the stages of the life cycle of an individual. The subject of the study is human capital and an assessment of its quality. The purpose of the study is to clarify the structure of human capital, to identify the features of its evaluation.

It is concluded that the following components of human capital exist: health capital, education capital, intellectual capital, professional capital, labor capital, manager capital, capital of social adaptation. Arguments are given about that the quality of the formed human capital of an individual can be confirmed by various forms of public and state evaluation.

Keywords: the quality of human capital, the structure of human capital, the capital of health, the capital of education, intellectual capital, professional capital, the capital of social adaptation, labor capital, manager capital

Вопросами составляющих человеческого капитала на протяжении веков занимаются как зарубежные, так и российские ученые. Многие из них отождествляют профессиональный капитал с трудовым капиталом, не выделяют капитал социальной адаптации и пр. Данные проблемы до сих пор остаются не полностью изученными и представляют научный интерес.

Совершенно очевидно, что формирование и расходование человеческого капитала по спирали включает прямое и обратное движение с иногда неопределенными «возвратами» к предшествующим стадиям, со скачкообразной заменой одного 
состояния другим. Именно поэтому изучать составляющие человеческого капитала следует по этапам жизненного цикла каждого индивида.

Первый этап жизненного цикла формирования и расходования человеческого капитала индивида занимает шесть-семь лет его жизни [1].В этот период особенно важное значение имеет воспитание родителями, работниками детских садов, общественных организаций, которые участвуют в развитии человеческого капитала индивида. Идет формирование костно-мышечной системы, биохимических механизмов, всех подсистем организма как основы здоровья и силы индивида. В раннем возрасте человек осваивает язык, речь, манеру поведения и общения, начинает мыслить. В этот же период формируется чувственный мир индивида, его психомоторные реакции и устойчивость нервной системы. Из чего следует, что в человеческий капитал входит здоровье индивида, его социальная адаптация через поведение, реакцию, общение, а также интеллект.

Второй этап жизненного цикла формирования человеческого капитала длится с 7 до 17-18 лет, это этап обучения детей в школе.

Совершенно очевидно, что общее образование расширяет границы здоровья индивида, его социальной адаптации, но в тоже время формирует такой элемент человеческого капитала как культурно-нравственный капитал [2], общая образованность индивида. Но культурно-нравственный капитал мы включаем в капитал социальной адаптации индивида.

Это связано с тем, что общее среднее образование закладывает базовый объем знаний индивидов в области естественных, общественных и гуманитарных наук.

Одновременно завершается социализация личности, осознание ею гражданских прав и обязанностей, эталон поведения для индивида. Большая часть индивидов вливается в общественный процесс неконфликтно, тогда как отдельные индивиды начинают отличаться девиантным поведением.

Появляются ошибки в работе системы образования и воспитания в виде подростковой преступности, наркомании, девиантное поведение и конфликты, протестные молодежные организации и группы [3].

Фактически, на данном этапе продолжает закладываться такой элемент человеческого капитала как здоровье, социализация и образованность, интеллектуализация личности.

К следующему этапу жизненного цикла формирования и расходования человеческого капитала следует отнести получение профессионального образования через производственное и профессиональное обучение.

Теория и практика профессионального образования позволяют индивиду получить квалификацию, развить трудовые навыки, профессиональные способности.

Профессиональные знания, умения и навыки доводятся до определенного уровня, оцениваемого аттестационными комиссиями, присваивающими аттестаты, удостоверения, дипломы о квалификации индивида.

На этом этапе поддерживается так называемый капитал здоровья индивида, в полной мере активируется капитал социальной адаптации, а к капиталу образованности, интеллектуальному капиталу добавляется профессиональный капитал $[3,4]$.

На следующем этапе жизненного цикла проявляется трудовой капитал и организационный капитал индивида ( капитал менеджера). В этот же период следует поддерживать капитал здоровья, так как он начинает активно расходоваться, применять (расходовать) капитал образованности, интеллекта, профессионализма; трудовой капитал; совершенствовать капитал социальной адаптации. Практически такие составляющие человеческого капитала как капитал образованности, интеллекта и профессионализма начинают пополняться за счет формируемого трудового капитала и 
при помощи перманентного обновления профессиональных знаний, совершенствования навыков социализации личности.

Процесс формирования и расходования капитала менеджера специфичен [4]. Склонность к бизнесу, предприимчивость, организаторские способности проявляются не у всех индивидов индивидов [5]. Но если профессиональное образование позволило выявить организационно-предпринимательские способности индивида, то на данном этапе начинает формироваться не только трудовой капитал, но и капитал менеджера.

Также своеобразно и развитие интеллектуального капитала, которое происходит на всех этапах формирования и расходования человеческого капитала индивида. Его развитие у конкретного человека выражается в творческих способностях созидать новые знания, новые ценности, конструировать новые изделия и новые технологии $[6,7,8]$; в креативности выполнения заданий, организации трудовых процессов и пр.

Такой этап жизненного цикла формирования человеческого капитала как трудовая деятельность индивида одновременно свидетельствует и о его расходовании. На данном этапе необходимо балансировать интеллектом, знаниями, здоровьем, креативностью, т.е. всеми сформированными и поддерживаемыми составляющими человеческого капитала.

Наибольший расход происходит капитала здоровья, что требует постоянной подпитки и обновления. Тогда как интеллектуальный капитал, капитал образованности и профессионализма перерастают в капитал предприятий, организаций, на которых работают индивиды.

По окончании трудовой деятельности процесс формирования человеческого капитала останавливается не у всех индивидов. Это связано с саморазвитием личности, с переоценкой ценностей и пр. Отдельные виды индивидов переключаются на семью и в данном случае, передают свой сформированный капитал подрастающему поколению. Другие - продолжают развивать свой интеллектуальный капитал, делятся им с окружающими, участвуют в общественных мероприятиях, пишут книги, проводят научные исследования и пр.

Таким образом, можно подтвердить специфическую черту человеческого капитала - воспроизводимость и дискретность формирования и расходования, которая дает основание утверждать, что она есть выражение движения по гегелевской спирали [9]. Человеческий капитал не растет прямолинейно и не остается в пределах замкнутого жизненного цикла индивида. Отдельные составляющие человеческого капитала расходуются и пополняются.другие - не пополняются, третьи - накапливаются. Человеческий капитал непрерывно меняется, обновляется, движется по спирали.

Качество человеческого капитала можно представить как устойчивую совокупность свойств его основных составляющих, образующих врожденные или приобретенные профессиональные, интеллектуальные, трудовые, организаторские способности, способности здоровья, перманентно обогащающиеся и обновляющиеся, и проходящие различные стадии воспроизводства в процессе накопления и расходования здоровья, знаний, умений, трудовых навыков и других способностей, обеспечивающих качество труда и жизни.

Качество человеческого капитала можно подтвердить различными формами общественной и государственной оценки [10]. Например, капитал здоровья можно оценить по медицинским обследованиям и заключениям, по истории болезни, медицинской карточке индивида, по больничным листам, по экспертным оценкам продолжительности жизни. Капитал образованности и интеллекта по аттестату зрелости и характеристикам. Интеллектуальный уровень психологи оценивают по разным методикам [11]. Нравственность поведения оценивают коллеги по работе, родственники, лица, поддерживающие контакты и знающие человека лично. Правоохранительные органы, например, детские комнаты милиции, ведут досье на людей, совершивших проступки или преступления [12]. Профессиональный капитал 
оценивается по дипломам, сертификатам, принимаемым решениям, исполнению заданий. Рост квалификации, получение новой специальности подтверждается различными удостоверениями, аттестатами и дипломами.

Трудовой капитал подтверждается записями в трудовой книжке, производительности труда, характеристике и востребованности индивида. В трудовой книжке фиксируется опыт работы, достижения в труде отмечаются в характеристиках и рекомендательных письмах $[13,14]$. Служебная или трудовая карьера работника отмечается ростом его квалификации или повышением должности.

Таблищу 1

Оченка структуры и качества человеческого капитала индивида

\begin{tabular}{|c|c|c|}
\hline $\begin{array}{c}\text { Составляющие человеческого } \\
\text { капитала }\end{array}$ & Показатели качества & Формы общественной оценки \\
\hline Капитал здоровья & $\begin{array}{c}\text { 1.Состояние здоровья } \\
\text { 2.Наличие или отсутствие } \\
\text { заболеваний } \\
\text { 3. Потери времени по здоровью }\end{array}$ & $\begin{array}{c}\text { 1. Медицинская книжка ( история } \\
\text { болезни) } \\
\text { 2.Эксертиза, медицинское } \\
\text { заключение } \\
\text { 3. Больничные листы } \\
\end{array}$ \\
\hline Капитал образованности & 1. Базовый уровень образования & $\begin{array}{c}\text { 1.Аттестат } \\
\text { ( отметки) } \\
\text { 2. Характеристика } \\
\end{array}$ \\
\hline Интеллектуальный капитал & 1. Коэффициент интеллекта & $\begin{array}{c}\text { 1. Оценки окружения } \\
\text { ( креативность обучения, } \\
\text { выполнения заданий, общения) } \\
\text { 2. Патенты, изобретения } \\
\text { 3.Доход } \\
\end{array}$ \\
\hline $\begin{array}{c}\text { Капитал социальной } \\
\text { адаптации }\end{array}$ & $\begin{array}{c}\text { 2.Неконфликтность } \\
\text { 3.Факты девиантного поведения }\end{array}$ & $\begin{array}{c}\text { 1.Оценки окружения } \\
\text { 2.Досье правоохранительных } \\
\text { органов }\end{array}$ \\
\hline Профессиональный капитал & $\begin{array}{l}\text { 1. Уровень образования } \\
\text { 2.Профессиональный опыт }\end{array}$ & $\begin{array}{c}\text { 1. Тип диплома } \\
\text { 2.Характеристика, } \\
\text { востребованность } \\
\text { 3. Карьерный рост }\end{array}$ \\
\hline Трудовой капитал & $\begin{array}{l}\text { 1. Трудовые достижения и рост } \\
\text { 2. Производительность труда }\end{array}$ & $\begin{array}{c}\text { 1. Трудовая книжка } \\
\text { 2. Показатели } \\
\text { производительности труда }\end{array}$ \\
\hline Капитал менеджера & $\begin{array}{l}\text { 1. Собственный капитал } \\
\text { 2. Рейтинг предпринимателей } \\
\text { 3. Тип бизнеса }\end{array}$ & $\begin{array}{c}\text { 1. Документы о собственности } \\
\text { 2. Рейтинговые фирмы - } \\
\text { оценщики } \\
\text { 3. Форма участия }\end{array}$ \\
\hline
\end{tabular}

Наличие интеллектуального капитала, прежде всего, проявляется созданием объектов интеллектуальной собственности - патентов, авторских свидетельств, опытных образцов, других охранных документов на авторские права [15]. Капитал менеджера фиксируется в праве предпринимательской деятельности.

Таким образом, в обществе сформированы и законодательно закреплены различные формы оценки накопленного человеческого капитала и документальное оформление их уровня.

Человеческий капитал включает в себя такие составляющие как: капитал здоровья, капитал образованности, интеллектуальный капитал, капитал социальной адаптации, профессиональный капитал, трудовой капитал, капитал менеджера. Все составляющие человеческого капитала необходимо обновлять и восстанавливать в процессе эксплуатации индивида. Можно сделать вывод, что в процессе трудовой деятельности интеллектуальный капитал, профессиональный капитал могут перерасти в капитал компании. 
1. Абдалхуссейн А.А.Д. Человеческий потенциал и человеческий капитал в производственной деятельности предприятия/ А.А.Д. Абдалхуссейн, М.С. Санталова// Социально-экономические явления и процессы.-2013.- № 6 (52).- С. 9-11.

2. Санталова М.С. Инновационный подход к управлению и оценки персонала// М.С. Санталова, С.С. Диденко//EuropeanSocialScienceJournal. - 2015. - № 1-2.- C. 86-90.

3. Николаева Ю.Р. Управление интеллектуальным капиталом предприятия/ Ю.Р. Николаева, М.С. Санталова, Е.А. Бунина: Воронеж, изд-во Истоки, 2011.-182c.

4. Санталова М.С. Интеллектуальный капитал в управлении компанией/ М.С. Санталова Ю.Р. Николаева// Сегодня и завтра Российской экономики.- 2009.- №25.- С. 35-36.

5. Дятлов С.А. Основы теории человеческого капитала/ С.А. Дятлов: Издательство СанктПетербургского Государственного Университета Экономики и Финансов, 1994.-156c.

6. Добрынин А.И. Человеческий капитал в транзитивной экономике/ А.И. Добрынин, С.А. Дятлов, Е.Д.Цыренова : Москва, Наука, 1999.- 312с.

7. Карпенко Е.3. Формирование человеческого капитала в условиях перехода к инновационной экономике/ Е.3. Карпенко: КноРус,2017 - 174с.

8. Развитие человеческого капитала/ под общей ред. В.А. Мау, Т.Л. Клячко: Москва, РАНХиГС, 2016 $-620 \mathrm{c}$.

9. Владимирова М.П. Становление теории человеческого капитала в рыночной экономике/ M.A. Владимирова, А.И. Козлов: Москва, КноРус, 2016 - 160с.

10. Курнышева И.Р. Особенности человеческого капитала российской экономики в конкурентном мире/ И.Р. Курнышева: сб. Современная конкуренция.- №6 (14).- 2009. - С12.

11. Жуковская И.Ф. Человеческий капитал и конкурентоспособность российской экономики/ И.Ф. Жуковская: сб. Современная конкуренция.- №6 (30).-2011.- С.132

12. Громова Н.В. Роль человеческого капитала в обеспечении конкурентоспособности современных компаний/ Н.В. Громова: сб. Современная конкуренция.- №6 (48).-2014

13. Помулева Н. Управление человеческим капиталом/ Н. Помулева: LAP LambertAcademicPublishing, 2012-156c.

14. Гарафиев И.З. Инновационный человеческий капитал и когнитивный труд работников / И.3. Гарафиев: БИБКОМ, 2016 -285с.

15. Поляков К.Л. Оценка человеческого капитала в профессиональном футболе / К.Л. Поляков, Л.В. Жукова: сб. Прикладная эконометрика.- №1(29).- 2013-С.45.

\section{Тарабановская С.В., Попова И.В. \\ PR как один из важных элементов маркетинговых коммуникаций вуза}

Луганский национальный университет имени Тараса Шевченко (ЛНР, Луганск)

doi:10.18411/spc-8-03-2018-15

idsp: 000001:spc-8-03-2018-15

\section{Аннотация}

В статье изучены подходы к определению таких понятий как: «маркетинговые коммуникации» и «Паблик рилейшнз» в трудах ученых. Определены инструменты PR, которые целесообразно использовать в сфере образования. Сформулировано сущность и значение PR для высшего учебного заведения. В завершении предложены ряд направлений деятельности PR в вузе.

Ключевые слова: маркетинговые коммуникации, Паблик рилейшнз, инструменты PR, образовательная услуга, имидж, высшее образование.

На сегодняшний день потенциальные потребители образовательных услуг нуждаются в достоверной информации о желаемом образовании, в выпускниках и налаживании долгосрочного сотрудничества. С этой целью они согласны платить за это свои деньгии потратитьусилия, которые приведутк тесным партнерским отношениям.

Высшие учебные заведения, в свою очередь, имеют широкий спектр образовательных услуг, выпускников, необходимость в формировании профессиональных и культурных компетенций. Весь этот потенциал вузы могут предложить рынку, но для этого необходима коммуникация, которая должна исходить от учреждения. Именно от учреждения, так как у предприятий-работодателей, да и у 